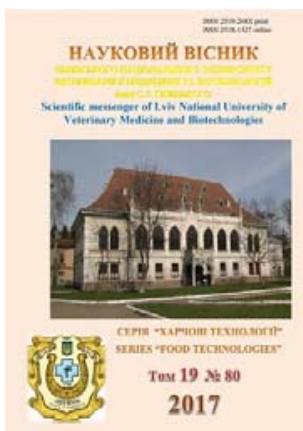

Науковий вісник Львівського національного університету ветеринарної медицини та біотехнологій імені С.З. Гжицького

Scientific Messenger of Lviv National University of Veterinary Medicine and Biotechnologies

doi:10.15421/nvlvet8023

ISSN 2519-268X print

ISSN 2518-1327 online

http://nvlvet.com.ua/

УДК 338.27/ 637.51

\title{
Амінокислотний склад та біологічна цінність м'ясних напівфабрикатів 3 використанням рослинної сировини та білково-жирових емульсій
}

\author{
Д.А. Шведюк ${ }^{1}$, В.М. Пасічний ${ }^{1}$, І.Г. Радзієвська ${ }^{1}$, Ю.А. Мацук ${ }^{2}$ \\ shvedyuk.d@ukr.net,pasww1@ukr.net,logos2007@ukr.net,lyly2006@ukr.net \\ ${ }^{1}$ Національний університет харчових технологій, \\ вул. Володимирська, 68, Київ, 01033, Україна; \\ ${ }^{2}$ Дніпровський наџіональний університет імені Олеся Гончара, \\ проспект Гагаріна, 72, Дніпро́, 49000, Україна
}

\begin{abstract}
У статті розглянуто вплив внесення білково-жирових емульсій та рослинної сировини у рецептури м'ясних напівфабрикатів із м'яса птиці на показники біологічної ијінності та амінокислотний склад готового продукту.

Досліджено напівфабрикати, рецептура яких включала як основну сировину такі складові: філе та стегно курчатбройлерів, сало хребтове свиняче, клітковину пшеничну гідратовану, порошок із зеленої маси подорожника. Вибір складових компонентів рецептури здійснено з огляду на можливість моделювання повноцінного за жирнокислотним та амінокислотним складом продукту, а також введення функиіональних інгредієнтів: клітковини пшеничної та порошку зеленої маси подорожника. Як основні дослідні показники визначали амінокислотний склад та біологічну иінність готової продукції. Для иього хроматографічним методом проведено визначення вмісту незамінних амінокислот у готовому продукті та розраховано критерії біологічної иінності. СКОРи усіх незамінних амінокислот перебували в межах 73-114\%, а значення коефіцієнту розбалансованості амінокислотного СКОРу $-18,96 \%$.

Зроблено висновок про позитивний вплив внесення білково-жсирових емульсій та рослинної сировини у рецептури м'ясних напівфабрикатів із м'яса птииі на біологічну цінність.

Ключові слова: м'ясні напівфабрикати, рослинна сировина, біологічна цінність, біологічна ефективність, функиіонально-технологічні показники, білково-жирові емульсії, амінокислотний склад.
\end{abstract}

\section{Аминокислотный состав и биологическая ценность мясных полуфабрикатов с использованием растительного сырья и белково-жировых эмульсий}

\author{
Д.А. Шведюк ${ }^{1}$, В.М. Пасичный ${ }^{1}$, И.Г. Радзиевська ${ }^{1}$, Ю.А. Мацук ${ }^{2}$ \\ shvedyuk.d@ukr.net, pasww1@ukr.net, logos2007@ukr.net, lyly2006@ukr.net \\ ${ }^{1}$ Национальный университет пищевых технологий, \\ ул. Владимирская, 68, Киев, 01033, Украина; \\ ${ }^{2}$ Днепровский национальный университет имени Олеся Гончара, \\ проспект Гагариная, 72, Днепр, 49000, Украина
}

\begin{abstract}
В статье рассмотрено влияние внесения белково-жировых эмульсий и растительного сырья в рецептуры мясных полуфабрикатов из мяса птицы на показатели биологической ценности и аминокислотный состав готового продукта.

Исследовано полуфабрикаты, рецептура которых включала в качестве основного сырья следуюшие составляюшие: филе и бедра иьыплят-бройлеров, сало хребтовое свиное, клетчатка пшеничная гидратированная, порошок из зеленой массы подорожника. Выбор составляюших компонентов рецептуры осуществлен, учитывая возможность моделирования полноиенного по жирнокислотному и аминокислотному составу продукта, а также введение функииональных ингредиентов, 6
\end{abstract}

\section{Citation:}

Shvedyuk, D., Pasichnyi, V., Radzievska, I., Matsuk, Y. (2017). Amino acid composition and biological value of meat semi-finished products with use of plant raw material and protein-fatty emulsions. Scientific Messenger LNUVMB, 19(80), 111-114. 
качестве которых выбрано клетчатку пшеничную и порошок зеленой массы подорожника. В качестве основных исследованных показателей определяли аминокислотный состав и биологическую иенность готовой продукции. Для этого хроматографическим методом проведено определение содержания незаменимых аминокислот в готовом продукте и проведен расчет критерия биологической иенности. СКОРы всех незаменимых аминокислот находились в пределах 73-114\%, а значение коэффициента разбалансированности аминокислотного СКОРа - 18,96\%.

Сделан вывод о положительном влиянии внесения белково-жировых эмульсий и растительного сырья в рецептуры мясных полуфабрикатов из мяса птицьь на их биологическую изенность.

Ключевые слова: мясные полуфабрикаты, растительное сырье, биологическая иенность, биологическая эффективность, функционально-технологические показатели, белково-жировые эмульсии, аминокислотный состав.

\title{
Amino acid composition and biological value of meat semi-finished products with use of plant raw material and protein-fatty emulsions
}

\author{
D. Shvedyuk ${ }^{1}$, V. Pasichnyi ${ }^{1}$, I. Radzievska ${ }^{1}$, Y. Matsuk $^{2}$ \\ shvedyuk.d@ukr.net, pasww1@ukr.net,logos2007@ukr.net, lyly2006@ukr.net \\ ${ }^{I}$ National University of Food Technologies, \\ Vladimirskaya Str., 68, Kiev, 01033, Ukraine; \\ ${ }^{2}$ Oles Honchar Dneprov National University, \\ Gagarina Str., 72, Dnepr, 49000, Ukraine
}

In the article is considered the influence of protein-fat emulsions and plant raw materials introducing into the formulas of meat semi-finished products from poultry meat on the biological value indices and the amino acid composition of the finished product.

There were studied semi-finished products, the formula of which included the following components as the main raw material: chicken and broiler fillets and thighs, sprouted pig fat, wheat hydrated cellulose, green plantain seed powder. The choice of the constituent formulation components was made taking into account the possibility a full-fat fatty acid and amino acid composition modeling and also the introduction of functional ingredients, such as wheat fiber and green plantain seed powder. The basis of the selected formulation is broiler chickens meat, the amount of which is $42.5 \%$, the protein-fat emulsion based on modified fats and wheat fiber with a 14:6 hydration degree. The protein-fat emulsion contained pigskin proteins and dry whey.

As the main research indicators, were determined the amino acid composition and biological value of the finished product. For this purpose, the chromatographic method was used to determinate the content of essential amino acids in the finished product and to calculate the biological value criteria. Soon, all essential amino acids were in the range of 73-114\%, and the value of the amino acid imbalance coefficient was $18.96 \%$.

The calculated values of biological value are the coefficient of imbalance of the amino acid composition (CIAAC), the coefficient of biological value $(B V)$, and the utility ratio. The values obtained allow us to conclude that the developed semi-finished products can be classified as full-fledged food products. Based on the obtained data, it is promising to improve the research formula for semifinished products in order to enrich it with limiting amino acids based on proteins of animal origin.

Key words: meat semi-finished products, vegetable raw materials, biological value, biological efficiency, functionaltechnological indicators, protein-fat emulsions, amino acid composition.

\section{Вступ}

Розширення асортименту м'ясних січених напівфабрикатів $\epsilon$ актуальним з огляду на стабільний попит населення (Vlasenko and Levyc'ka, 2017). Не в останню чергу можливості розширення асортименту даної групи продуктів продиктовані зростанням ролі на ринку функціональних та оздоровчих продуктів (Kozonova and Povarova, 2015).

Перспективними напрямками досліджень 3 огляду на зниження собівартості виробництва і оптимізацію біологічної цінності та ефективності $\epsilon$ внесення у рецептури замінників м'яса та рослинної сировини. Як заміну частини основної м'ясної сировини доцільним $€$ внесення білково-жирових емульсій на основі купажованих жирів та тваринних білків (Shvedjuk et al., 2016; Ukrai'nec' et al., 2017).

Купажовані жири за своєю природою є поєднанням кількох видів рослинних олій, підібраних за жирно кислотним складом так, щоб оптимізувати їхню біологічну ефективність. Ще однією особливістю даного виду сировини є підвищення функціональнотехнологічних показників внаслідок синергетичних ефектів взаємодії між оліями, що входять у склад жиру (Mank et al., 2014). Використання купажованих жирів у технології м'ясних січених напівфабрикатів дозволяє збагатити вироби за лімітуючими жирними кислотами (Shvedjuk et al., 2017).

Як тваринні білки, що входять до складу білковожирових емульсій, обрано суху молочну сироватку та білок свинячої шкурки. У поєднанні з м'ясом птиці, що є основною сировиною січених м'ясних напівфабрикатів, використання даного виду емульсій дозволило оптимізувати амінокислотний склад продукту.

При розробці функціонального продукту важливим $\epsilon$ вибір джерела функціонального інгредієнту. Негативний ефект введення зеленої маси в нативному вигляді полягає в їі слабкій органолептичній сумісності 3 м'ясною сировиною і підвищенні активності води (а як наслідок - зменшення терміну зберігання) через високий вологовміст зеленої частини рослин. Введення в формі гранул може бути розумною альтернативою, проте справляє дуже негативний вплив на структурно-механічні властивості готових виробів, окрім того $\epsilon$ менш економічно доцільним. Введення зеленої маси рослин найбільш доцільне в вигляді 
сухого порошку. Зважаючи на наведені вище перспективи, джерелом функціонального інгредієнту зелену масу подорожника.

Листя подорожника великого містить полісахариди $(20 \%)$, представлені пектиновими речовинами та нейтральними гліканами. Наявні також маніт, сорбіт, алантоїн, іридоїди (аукубін та каталпол), стероїди, флавоноїди (похідні лютеоліну, кверцетину, апігеніну та ін.), дубильні речовини (Grodzyns'kyj, 1992).

Метою проведених досліджень було дослідити вплив внесення білково-жирових емульсій на основі купажованих жирів і тваринних білків у поєднанні із рослинною сировиною на біологічну цінність м'ясних січених напівфабрикатів.

\section{Матеріал і методи досліджень}

Об'єктом досліджень є м'ясні січені напівфабрикати із м'яса курчат-бройлерів, що містять у своїх рецептурах білково-жирові емульсії на основі купажованих жирів двох типів, клітковину злаків та порошок зеленої маси подорожника.

Основою обраної рецептури $є$ м'ясо курчатбройлерів, кількість якого становить 42,5\%, білковожирова емульсія на основі купажованих жирів та пшенична клітковина зі ступенем гідратації 14:6. Білково-жирова емульсія містила у своєму складі білки свинячої шкурки та суху молочну сироватку.

Рецептури досліджуваних напівфабрикатів наведено у табл. 1.

Рецептури дослідних зразків

Таблиияя 1

\begin{tabular}{|l|c|c|}
\hline \multicolumn{1}{|c|}{ Сировина } & \multicolumn{2}{|c|}{ Варіант рецептури } \\
\cline { 2 - 3 } & 1 & 2 \\
\hline М'ясо курчат-бройлерів, \% & 42,5 & 42,5 \\
\hline Клітковина, \% & 5,6 & 5,6 \\
\hline Вода, \% & 12,4 & 12,4 \\
\hline $\begin{array}{l}\text { Концентрат зеленої маси } \\
\text { подорожника, \% }\end{array}$ & 2,0 & 2,0 \\
\hline Сало хребтове свиняче, \% & 10,0 & 10,0 \\
\hline Емульсія, \%, з яких: & 22,5 & 22,5 \\
\hline Білок свинячої шкурки, \% & 3,6 & 3,6 \\
\hline $\begin{array}{l}\text { Купажований жир на основі } \\
\text { ріпакової олії, \% }\end{array}$ & 4,5 & - \\
\hline $\begin{array}{l}\text { Купажований жир на основі } \\
\text { пальмової олії, \% }\end{array}$ & - & 4,5 \\
\hline Суха молочна сироватка, \% & 0,9 & 0,9 \\
\hline Вода, \% & 13,5 & 13,5 \\
\hline Панірувальні сухарі, \% & 5,0 & 5,0 \\
\hline
\end{tabular}

До складу рецептури дослідних зразків також входив концентрат зеленої маси подорожника та сало хребтове свиняче. Напівфабрикати, розроблені за варіантами рецептур, під номерами у 1 і 2 відрізнялись за типом купажованого жиру в рецептурі. Рецептуру купажованого жиру першого типу складали рослинні олії у таких відсоткових співвідношеннях: ріпакова - 63\%, пальмова - 7\%, пальмовий олеїн 30\%. Рецептура другого типу жиру містила 70\% пальмової, 25\% кукурудзяної і 5\% лляної олії. У напівфабрикатах після термічної обробки було визначено вміст незамінних амінокислот для обох рецептур. Рецептури відрізнялись тільки типом купажованого жиру в рецептурі, тому їх амінокислотний склад $\epsilon$ однаковим.

Визначення вмісту незамінних амінокислот проведено хроматографічним методом (Ovchinnikova, 1974; Kozarenko et al., 1981). Для оцінки біологічної цінності напівфабрикату розраховано амінокислотний СКОР (відношення вмісту амінокислот білка продукту до аналогічного показника еталонного білка за даними ФАО/BOО3) (Pasichnyj, 2008). Для оцінки ступеня використання білка здійснено розрахунок коефіцієнту розбалансованості амінокислотного складу (КРАС), який $є$ середнім арифметичним різниць СКОРів незамінних амінокислот до СКОРу першої лімітуючої амінокислоти (Pasichnyj, 2003).

$$
\mathrm{KPAC}=\Sigma_{\mathrm{i}=1}^{8}(\mathrm{I}-\mathrm{L}) / 8 \text {, де }
$$

I - значення амінокислотного СКОРу і-тої амінокислоти, \%

$\mathrm{L}$ - значення амінокислотного СКОРу лімітуючої амінокислоти, \%.

Розрахунок біологічної цінності зразків здійснювали за формулою (Majevs'ka, 2015).

$$
\text { БЦ=100-КРАС, \% }
$$

Для оцінки збалансованості незамінних амінокислот відносно до еталонного білка розраховували коефіцієнт утилітарності (U)

$$
U=A C_{\min } \frac{\sum_{j=1}^{8} H A K_{e k}}{\sum_{j=1}^{8} H A K_{k}}
$$

де $A C_{\min }$ - мінімальний зі СКОРів незамінних амінокислот,

$$
\sum_{j=1}^{8} H A K_{e k}-\text { сумарний вміст незамінних амінокислот }
$$
у білку еталону, мг/г білку. $\sum_{j=1}^{8} H A K_{k}-$ сумарний вміст незамінних амінокислот у білку продукту, мг/г.

\section{Результати та їх обговорення}

У ході досліджень визначено амінокислотний склад готових виробів. СКОРи усіх амінокислот перебували в межах від 73 до 114\%. Найбільший СКОР зафіксовано для лізину $-113,45 \%$. Лімітуючою амінокислотою $є$ ізолейцин, СКОР якого складає 73\%. Значення СКОРу амінокислот, для яких цей показник розраховується парними групами - метіонін-цистеїн та тирозин-феніаланін, становлять відповідно 91,14\% (метіонін-цистеїн) та 108,0\% (тирозин-фенілаланін). Амінокислотний склад наведено у таблиці 2. Після визначення амінокислотного складу проведено розрахунок коефіцієнта розбалансованості амінокислотного складу за формулою (1). Отримане значення КРАС - 18,96\%. На підставі значення КРАС можна визначити біологічну цінність (БЦ) за формулою (2), як різницю 100 та значення КРАС. Отримане значення біологічної цінності - 81,04\%. Для визначення коефіцієнту утилітарності використано формулу (3). Отримане значення коефіцієнту утилітарності - 0,82 . 
Амінокислотний склад та СКОРи незамінних амінокислот у дослідному зразку

\begin{tabular}{|c|c|c|c|}
\hline \multirow[t]{2}{*}{ Амінокислота } & Середній вміст у зразку & \multirow{2}{*}{$\begin{array}{c}\text { Еталонний білок за } \\
\text { ФАО/ВООЗ, мг/1г білка }\end{array}$} & \multirow[t]{2}{*}{ Амінокислотний СКОР зразку, \% } \\
\hline & 1мг/1г білка & & \\
\hline Лізин & 62,4 & 55,00 & 113,45 \\
\hline Треонін & 38,4 & 40,00 & 96,00 \\
\hline Метіонін & 16,1 & \multirow{2}{*}{35,00} & \multirow{2}{*}{91,14} \\
\hline Цистеїн & 15,8 & & \\
\hline Валін & 38,2 & 50,00 & 76,40 \\
\hline Ізолейцин & 29,2 & 40,00 & 73,00 \\
\hline Лейцин & 77,8 & 70,00 & 111,14 \\
\hline Тирозин & 26,3 & \multirow{2}{*}{60,00} & \multirow{2}{*}{108,00} \\
\hline Фенілаланін & 38,5 & & \\
\hline Триптофан & 6,25 & 6,60 & 94,70 \\
\hline Сума & 310,45 & 350,00 & \\
\hline
\end{tabular}

\section{Висновки}

Розраховані показники біологічної цінності - коефіцієнт розбалансованості амінокислотного складу (КРАС), коефіцієнт біологічної цінності (БЦ) та коефіцієнт утилітарності. Отримані значення дозволяють зробити висновок, що розроблені напівфабрикати можуть бути віднесені до повноцінних продуктів харчування.

Перспективи подальших досліджень. Перспективним є удосконалення дослідної рецептури напівфабрикатів $з$ метою збагачення його за лімітуючими амінокислотами на основі білків тваринного походження.

\section{Бібліографічні посилання}

Vlasenko, V., Levyc'ka, I. (2017). Suchasnyj stan ta problemy vyrobnyctva i spozhyvannja mjasa naselennjam Ukrai'ny. Agrarna nauka ta harchovi tehnologii'. 1, 178-186 (in Ukrainian).

Kozonova, Ju., Povarova, N. (2015). Providni tendencii' u rozvytku jevropejs'kogo rynku funkcional'nyh produktiv. Holodyl'na tehnika ta tehnologija. 51, 9196 (in Ukrainian).

Shvedjuk, D., Pasichnyj, V., Prohorenko, Zh. (2016). Doslidzhennja fizyko-himichnyh vlastyvostej napivfabrykativ m'jasnyh $\mathrm{z}$ dodavannjam bilkovozhyrovyh emul'sij na osnovi kupazhovanyh zhyriv. Visnyk Nac. tehn. un-tu «HPI»: zb. nauk. pr. Ser.: Novi rishennja $v$ suchasnyh tehnologijah. Bulletin of National Technical University «KhPI»: coll. of sci. papers. Ser.: New solutions in modern technologies. Harkiv: NTU «HPI». 42(1214), 223-227 (in Ukrainian).

Ukrai'nec', A., Pasichnyj, V., Shvedjuk, D., Macuk, Ju. (2017). Doslidzhennja zdatnosti do proteolizu m'jasnyh sichenyh napivfabrykativ funkcional'nogo pryznachennja. Naukovyj visnyk L'vivs'kogo nacional'nogo universytetu veterynarnoi' medycyny ta bio- tehnologij imeni S. Z. G'zhyc'kogo. Serija: Harchovi tehnologii'. 75, 129-133 (in Ukrainian).

Mank, V.V., Radzijevs'ka, I.G., Shemanskaja, E.Y. (2014). Proyzvodstvo spredov sbalansyrovannogo sostava na slyvochno-rastytel'noj zhyrovoj osnove (in Russian).

Shvedjuk, D., Pasichnyj, V.M., Radzijevs'ka, I.G. (2017). Modeljuvannja zhyrnokyslotnogo skladu sichenyh napivfabrykativ z m'jasa ptyci z vykorystannjam modyfikovanyh zhyriv. Visnyk Nac. tehn. un-tu «HPI»: zb. nauk. pr. Ser.: Novi rishennja v suchasnyh tehnologijah. Bulletin of National Technical University «KhPI»: coll. works. Ser.: New solutions in modern technologies. Harkiv: NTU «HPI». 7(1229), 225-232 (in Ukrainian).

Grodzyns'kyj, A.M. (1992). Likars'ki roslyny. K. (in Ukrainian).

Ovchinnikova, Ju.A. (1974). Novye metody analiza aminokislot, peptidov i belkov. Per. s angl. kand. him. nauk Ju.B. Alahova [i dr.]. Moskva: Mir (in Russian).

Kozarenko, T.D., Zuev, S.N., Muljar, N.F. (1981). Ionoobmennaja hromatografija aminokislot : Teoreticheskie osnovy i praktika: nauchnoe izdanie. Sibirskij in-t fiziologii i biohimii rastenij AN SSSR. Novosibirsk: Nauka (in Russian).

Pasichnyj, V. (2008). Mozhlyvosti pidvyshhennja tehnologichnyh harakterystyk bilkovyh napovnjuvachiv. M'jasnyj biznes. 11, 28-32 (in Ukrainian).

Pasichnyj, V. (2003). Kryterii otsinky kharchovoi tsinnosti miasoproduktiv. Mjasnoj biznes. 8, 64-65 (in Ukrainian).

Majevs'ka, T. (2015). Aminokyslotna zbalansovanist' bilkiv promytyh rybnyh farshiv. Naukovi praci Nacional'nogo universytetu harchovyh tehnologij. 21(2), 197-202 (in Ukrainian).

Received 20.09.2017

Received in revised form 20.10.2017 Accepted 27.10.2017 